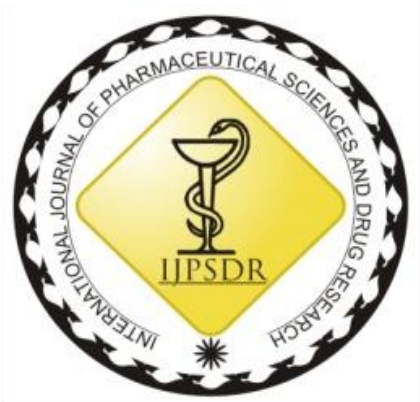

ISSN: 0975-248X

RESEARCH ARTICLE CODEN (USA): IJPSPP (cc) EY-NC-SA

\title{
Isolation and Structure Elucidation of Isoquercitrin from the Whole Herb of Hygrophila salicifolia (Acanthaceae)
}

\author{
Mehul K Bhatt ${ }^{*}$, Nehal Shah² \\ ${ }^{1}$ School of Pharmacy, R. K. University, Rajkot, Gujarat, India \\ 2Indubhai Patel College of Pharmacy \& Research Centre, Dharmaj, Gujarat, India
}

Copyright (C) 2019 Mehul K Bhatt et al. This is an open access article distributed under the terms of the Creative Commons AttributionNonCommercial-ShareAlike 4.0 International License which allows others to remix, tweak, and build upon the work non-commercially, as long as the author is credited and the new creations are licensed under the identical terms.

\begin{abstract}
There are a large number of traditional plants, their extracts and phytoconstituents presently used in modern medicine. There is a worldwide majority of the population that still relies on plants as a source of medicine. One of the medicinally useful plant is Hygrophila salicifolia. Hygrophila salicifolia is an erect herb (family: Acanthaceae). It has many medicinal uses like diuretic and anti inflammatory in traditional systems of medicine. Till date no data available for its Phytoconstituents therefore isolation of phytoconstituent was done from methanolic extract of Hygrophila salicifolia. Flavonoid was isolated for the first time from a Hygrophila salicifolia (Acanthaceae). Its structure was established on the basis of its spectroscopic data such as UV, IR, Mass, NMR, Melting point, HPTLC and laterally confirmed as Isoquercitrin.
\end{abstract}

Keywords: Hygrophila salicifolia, Mass, NMR, UV, IR, Melting point, flavonoid, Isoquercitrin.

DOI: 10.25004/IJPSDR.2019.110201

Int. J. Pharm. Sci. Drug Res. 2019; 11(2): 51-55

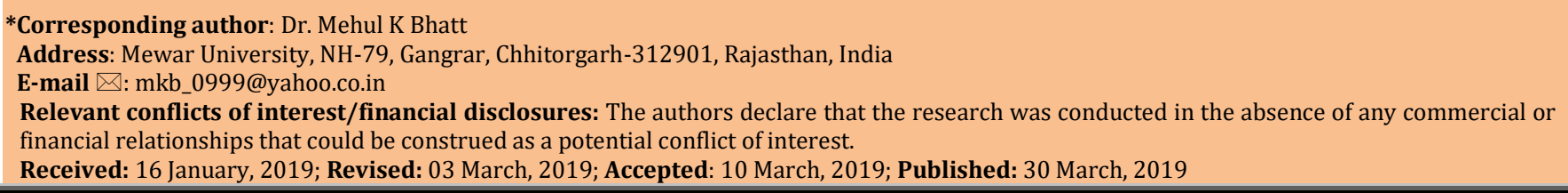

\section{INTRODUCTION}

The western society has become interested in natural products with general public acquiring herbal formulations. Nature has been a resource of therapeutic agents for thousands of year, and a remarkable number of modern phytoconstituents of therapeutical importance has been isolated from the natural sources. The majority of the isolated plant compounds are terpenoids, flavonoids and alkaloids and their structures are varied extremely and often very complex. [1] The whole herb of Hygrophila salicifolia has been advocated for the therapy of various diseases including jaundice, urinary infection, gouts, hepatic disorder, rheumatism, impotence, anti-bacterial and inflammation. ${ }^{[2]}$ It is an erect or ascending herb belongs to the family Acantheceae. It is bestowed with many medicinal uses in traditional systems of medicine including ayurveda. Seeds and leaves used as poultice on inflammatory swellings. Leaves are strongly diuretic. The plant is discovered in moist and marshy places throughout the greater part of India. Stems up to 3 feet long, more or less quadrangular, rooting at the lower nodes, leaves sub sessile, linear-lanceolate; flowers pale purple in dense axillary whorls, capsule oblong, seeds many, ovoid, compressed, mucilaginous, hairy. The leaves are eaten as pot- herb. They contain 
$8 \%$ ash rich in potassium and are strongly diuretic. In Malaya, the leaves are used as poulticing swellings. The seeds swell into a gelatinous shining mass with water and used in java, in poultices for headaches and fevers. They yield $25 \%$ of a fatty oil and contain traces of unidentified alkaloid, a bitter substance and $4 \%$ ash consisting chiefly of calcium phosphate and potassium chloride. [2-3] The plant has been reported to contain chlorophyll, pigments, gums, glucose, starch, fat, various minerals, alkaloids, flavanoids, tannins and sterols. ${ }^{[4-6]}$ In present days most of the people trust in herbal therapy to cure and prevent the diseases condition but There is questions ahead for scientists in Ayurveda for authenticating the claims in the Ayurvedic treatment to make the system universally acceptable. The plant Hygrophila salicifolia is well known for its diuretic and anti inflammatory uses in Ayurveda but till date no data available for its phytoconstituents, therefore isolation of the phytoconstituents, identification \& characterization by various spectroscopic methods (UV, IR, NMR, Mass), melting point and TLC is necessary. So the course of our search for secondary metabolites in this species led us to the isolation and characterization of flavonoid from the methanolic extract of the whole herb of Hygrophila salicifolia (family: Acanthaceae) laterally characterized it as isoquercitrin.

\section{MATERIAL AND METHODS}

\section{Authentification and Collection of Plant}

The whole herb of Hygrophila salicifolia was obtained in August-September 2013 from the local areas in and around Gujarat and Karnataka. It was identified, authenticated \& confirmed by taxonomist of Bioscience department and Shivam Institute of Science and paramedical College, Sardar Patel University, Vallabh Vidyanagar. A voucher specimen of the plant (Voucher No. MKB/Hs-1/12/SPSRC-13) was deposited in Pharmacognosy department, Shivam Pharmaceutical Studies \& Research Centre, Valasan, Anand, for future reference.

\section{Extraction}

The whole herb powder $(2 \mathrm{Kg})$ of Hygrophila salicifolia was successively extracted with different solvents starting from non-polar solvents (Petroleum ether, Toluene) to semi polar solvents (Chloroform, Ethyl acetate) and finally with five lit methanol for 10 hours and filtered. The methanolic extract was collected, filtered and dried under vacuum at a temperature below $70^{\circ} \mathrm{C}$,yielded a dark green semisolid residue $(8.3 \%, w / w) .5$ grams of methanolic extract of Hygrophila salicifolia was chromatographed on a glass column $\left(80 \times 3 \mathrm{~cm}^{2}\right)$ packed with silica gel G $(250 \mathrm{~g}$, 60$120 \#)$ as stationary Phase. The column was packed by wet packing. ${ }^{[7-8]}$

\section{Column}

The silica gel was mixed eluent $\mathrm{CHCl}_{3}$ with stationary phase in a beaker and then carefully poured into the column. Care was taken to avoid air bubbles inside the column. After wet packing cotton plug was kept on the stationary phase. Above it filter paper kept. Here three eluting solvents $\mathrm{CHCl}_{3}$, Ethyl acetate \& Methanol were used. Elution was started with $\mathrm{CHCl}_{3}(10: 0, \mathrm{v} / \mathrm{v})$ up to $100 \%$ followed by increasing gradient of ethyl acetate up to $100 \%$ and ending with $\mathrm{CHCl}_{3}$ : Ethyl acetate (0: 10, $\mathrm{v} / \mathrm{v}$ ) and then methanol was increased gradually ending with ethyl acetate: methanol (9:1, v/v). Gradient elution was performed by stepwise elution with $\mathrm{CHCl}_{3}$ : ethyl acetate: methanol with constant monitoring on TLC analysis. Each fraction of $25 \mathrm{ml}$ at the rate of 20 drops/minute was collected and tested on a TLC plate. Total 100 fractions were collected, and from there one compound had been isolated. Fractions with the same $R_{f}$ Value were mixed, evaporated and used for the further study. Fraction No. 89-92 (Ethyl acetate: methanol, 9: 1) showed single spot on TLC and confirmed by observing under UV $254 \mathrm{~nm}$ and Shinoda test. Stationary phase: Silica gel G, Mobile Phase: Ethyl acetate: glacial acetic acid: formic acid: Water (10:1.1:1.1:2.6\%, v/v/v/v), Saturation time: $20 \mathrm{~min}$, Observation: Under UV $254 \mathrm{~nm}$.

\section{Identification}

\section{Shinoda test}

To the isolated compound, added few $\mathrm{ml}$ of alcohol, boiled on the water bath and filter. To the filtrate, added concentrated $\mathrm{HCl}$ and magnesium ribbon. Pink to red colour was produced.

\section{Characterization of Isolated Compound}

Isolated compound was tested for further analysed by melting point and different spectroscopic methods like HPTLC, UV, FT-IR, Mass and H-NMR for characterization and structure elucidation. [9-12]

\section{Instrument}

The instruments used in the experiment were UVSpectrophotometer (UV-2450; Shimadzu Corporation, Japan), FT-IR (Shimadzu, 8400S, Japan), Mass spectrophotometer (Agilent model, 6890; Perkin Elmer, Germany), H-NMR (AVANCE-400 MHz Bruker Ltd., USA), Sonicator (Front line Electronics, India) Analytical balance (D. K. Scientific, India) HPTLC (Camag, Switzerland).

\section{UV Spectroscopy}

About $1 \mathrm{mg} / \mathrm{ml}$ stock solution was prepared by dissolving the required amount of accurately weighed isolated compound in methanol. The solution was analysed using a double beam UV-visible spectrophotometer in the range of $200-800 \mathrm{~nm}$, and $K_{\max }$ of compounds were determined using methanol as a blank.

\section{FTIR Spectroscopy}

About $1 \mathrm{mg}$ of the compound and $70 \mathrm{mg}$ of potassium bromide were weighed and placed in a clean mortar. The solids were mixed together using pestle until a very fine powder was obtained. The powder was placed inside the potassium bromide holder and was pressed to form a pellet. IR spectra for the compounds obtained in the range of $500-4000 \mathrm{~cm}^{-1}$ using FT-IR in 
potassium bromide disc and absorption peaks regardingwave numbers were observed.

\section{NMR Spectroscopy}

NMR spectra were obtained from a Bruker spectrometer using tetramethylsilane (TMS) as an internal standard in DMSO. Chemical shifts were in ppm concerning TMS. Coupling constants were in $\mathrm{Hz}$.

\section{Mass spectroscopy}

The analysis was performed in positive ionization mode with an electrospray interface. The mass to charge ratio recorded in the range of $100-550 \mathrm{~m} / \mathrm{z}$. The parameters for the capillary and $R_{\mathrm{f}}$ voltage were $80 \mathrm{~V}$ with nebulizer gas air at a pressure of 35 psi and curtain gas as nitrogen at a pressure of 10 psi.

Melting point

The melting point was determined by capillary tube method.

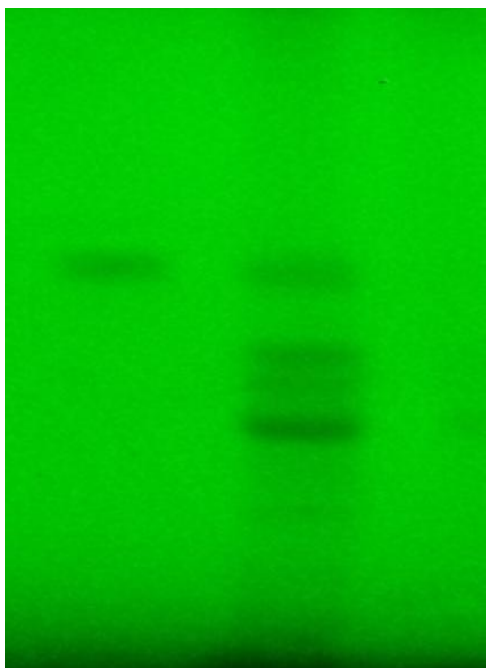

Fig. 1: Comparision TLC of isolated fraction and methanolic extract of Hygrophila salicifolia whole herb run in column chromatography Under UV254 nm

Table 1: Colour and $R_{f}$ value of isolated compound by column chromatography on TLC plate.

\begin{tabular}{ccccc}
\hline $\begin{array}{c}\text { Sample } \\
\text { No. }\end{array}$ & Fraction No & $\begin{array}{c}\mathbf{R}_{\mathrm{f}} \\
\text { Value }\end{array}$ & $\begin{array}{c}\mathbf{U V} \\
\mathbf{2 5 4 n m}\end{array}$ & $\begin{array}{c}\text { Shinod } \\
\text { a test }\end{array}$ \\
\hline $\begin{array}{c}\text { Isolated } \\
\text { compound }\end{array}$ & $\begin{array}{c}(89-92) \\
\text { Ethyl acetate: methanol } \\
(9: 1, \mathrm{v} / \mathrm{v})\end{array}$ & 0.76 & $\begin{array}{c}\text { Dark } \\
\text { black }\end{array}$ & Positive \\
\hline
\end{tabular}

Table 2: The data from the UV spectrum of the isolated compound

\begin{tabular}{ccc}
\hline \multirow{2}{*}{ Sample } & \multicolumn{2}{c}{$\lambda_{\max }$} \\
\cline { 2 - 3 } & $\begin{array}{c}\text { Before addition of 0.5M } \\
\text { NaOH }\end{array}$ & $\begin{array}{c}\text { After addition of 0.5M } \\
\mathbf{N a O H}\end{array}$ \\
\hline Isolated & $359.24 \mathrm{~nm}$ & $404.7 \mathrm{~nm}$ \\
Compound & $256.87 \mathrm{~nm}$ & $276.78 \mathrm{~nm}$ \\
\hline
\end{tabular}

\section{RESULTS}

One compound (0.029 g) was isolated by column chromatography in a different fraction. This compound was flavonoid glycoside which was confirmed by Shinoda test and TLC using solvent system Ethyl acetate: glacial acetic acid: formic acid: water (10:1.1:1.1:2.6, v/v/v/v) and observed under UV 254 nm (Table 1 \& Figure 1). Shinoda test was found to positive for isolated compound.

UV-Visible Spectroscopy
The results obtained by UV spectroscopy of isolated compound ( $\mathrm{R}_{\mathrm{f}}$ : 0.76$)$ in methanol and after addition of 2-4 drops of $0.5 \mathrm{M} \mathrm{NaOH}$ indicated the $\lambda_{\max }$ value (Table 2). The UV spectrum of the Methanolic solution of the isolated compound has characteristic bands at 359.24 $\mathrm{nm}, 256.87 \mathrm{~nm}$ respectively (Figure 2). After addition of 2-4 drops of $0.5 \mathrm{M} \mathrm{NaOH}$ in a Methanolic solution of the isolated compound, the bathochromic shift was observed (Figure 3).

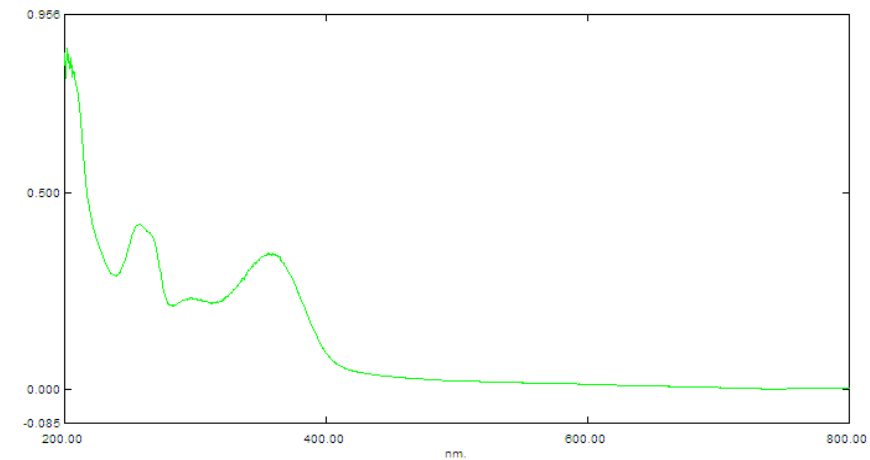

Fig. 2: UV Spectra of the Isolated compound in Methanol before addition of $0.5 \mathrm{M} \mathrm{NaOH}$

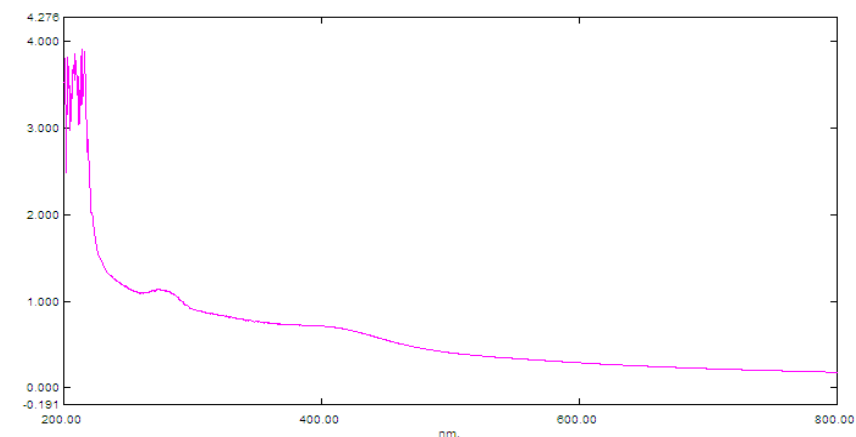

Fig. 3: UV Spectra of the Isolated compound in Methanol after addition $0.5 \mathrm{M} \mathrm{NaOH}$

Table 3: The data from the FTIR spectrum isolated compound

\begin{tabular}{cc}
\hline Peaks $\left.\mathbf{~ c m}^{-1}\right)$ & Functional group \\
\hline Isolated compound & O-H Alcohol group present \\
\hline 3346.97 & O-H stretching \\
2924.70 & -C-H stretching \\
1650.92 & Carbonyl C=O group present \\
1600.12 & Indicates benzene ring present \\
1454.39 & (aromatic) \\
1480.25 & -C-OH stretching \\
1365.07 & -C-OH Vibration \\
1306.79 & (Phenol) \\
1199.12 & $-\mathrm{C}-\mathrm{O}$ stretching \\
1110.40 & (I Alcohol) \\
1054.62 & Due to disubstitution of benzene \\
996.43 & Carbohydrate \\
929.4 &
\end{tabular}

\section{IR Spectra}

In the IR spectral analysis, the Peak at $3346.97 \mathrm{~cm}^{-1}$, $2924.70 \mathrm{~cm}^{-1}, 1650.92 \mathrm{~cm}^{-1}, 1600.12 \mathrm{~cm}^{-1}, 1454.39 \mathrm{~cm}^{-1}$ \& $1480.25 \mathrm{~cm}^{-1}, 1365.07 \mathrm{~cm}^{-1} \& 1306.79 \mathrm{~cm}^{-1}, 1199.12 \mathrm{~cm}^{-1}$ \& $1110.40 \mathrm{~cm}^{-1} 1054.62 \mathrm{~cm}^{-1}, 996.43 \mathrm{~cm}^{-1} \& 929.4 \mathrm{~cm}^{-1}$, $593.37 \mathrm{~cm}^{-1} \& 592.86 \mathrm{~cm}^{-1}$ was observed (Table $3 \&$ Figure 4). 
Mehul K Bhatt et al. / Isolation and Structure Elucidation of Isoquercitrin from the Whole Herb of Hygrophila.

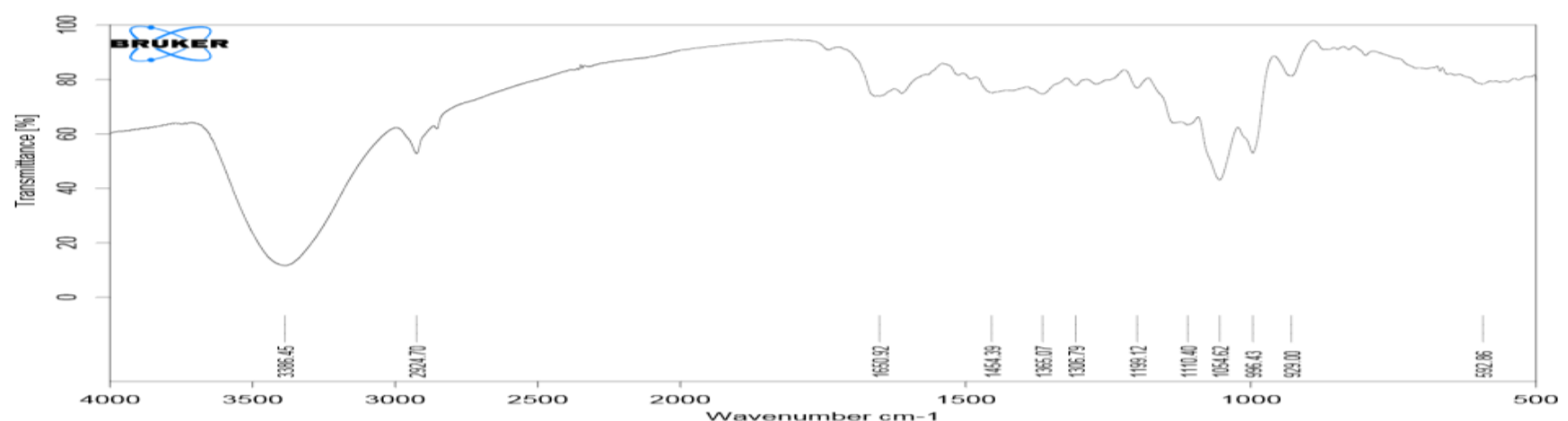

Fig. 4: IR spectrum of the isolated compound
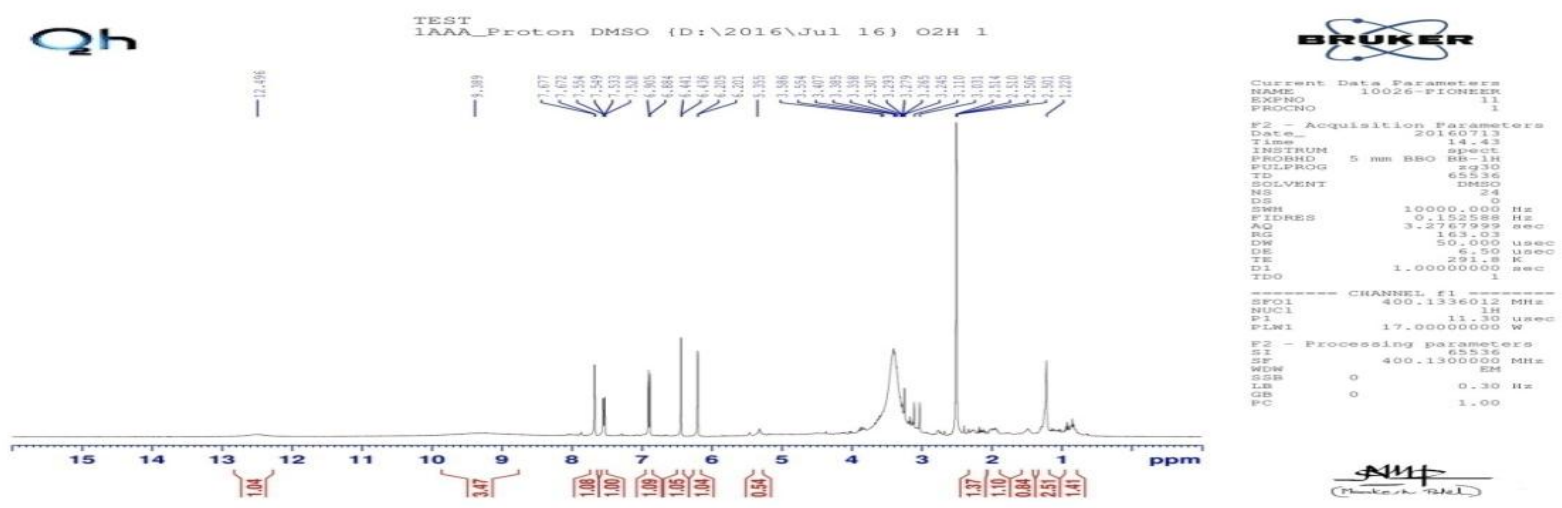

Fig. 5: NMR spectrum of the isolated compound
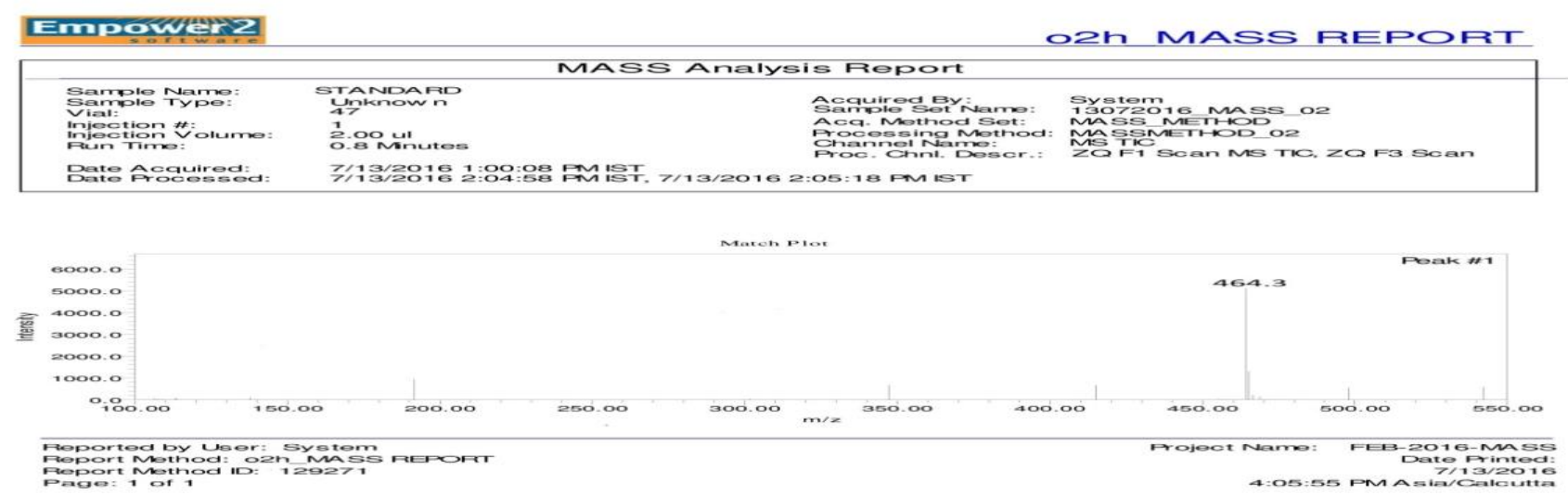

Fig. 6: Mass spectra of the isolated compound

Table 4: The data from the NMR spectrum of the isolated compound

\begin{tabular}{ccc}
\hline $\begin{array}{c}\text { No. of } \mathbf{H} \\
\text { atom }\end{array}$ & $\begin{array}{c}\boldsymbol{\delta} \text { value, } \\
\text { ppm }\end{array}$ & $\begin{array}{c}\text { Isolated compound } \\
\text { Integration, Multiplicity }(\mathbf{J}, \mathbf{H Z})\end{array}$ \\
\hline $1\left(1^{\prime}\right)$ & 5.35 & $1 \mathrm{H}, \mathrm{d} \mathrm{J}=6.8$ \\
$1\left(5^{\prime}\right)$ & 6.90 & $1 \mathrm{H}, \mathrm{d}, \mathrm{J}=8.7$ \\
$1(8)$ & 6.44 & $1 \mathrm{H}, \mathrm{d}, \mathrm{J}=2.3$ \\
$1(6)$ & 6.20 & $1 \mathrm{H}, \mathrm{d}, \mathrm{J}=2.3$ \\
$1\left(6^{\prime}\right)$ & 7.67 & $1 \mathrm{H}, \mathrm{d}, \mathrm{J}=8.5$ \\
$1\left(2^{\prime}\right)$ & 7.55 & $1 \mathrm{H}, \mathrm{dd}, \mathrm{J}=2.4$ \\
$-\mathrm{OH}$ & 9.38 & $(\mathrm{OH}) 11$ \\
$-\mathrm{OH}$ & 9.38 & $(\mathrm{OH}) 14$ \\
$-\mathrm{OH}$ & 9.38 & $(\mathrm{OH}) 12$ \\
$-\mathrm{OH}$ & 12.49 & $(\mathrm{OH}) 13$ \\
- & 3.11 & Sugar \\
- & 2.5 & Solvent peak \\
\hline
\end{tabular}

Table 5: Melting point

$$
\text { Compound }
$$
$241^{\circ} \mathrm{C}-242^{\circ} \mathrm{C}$
Melting Point $\left({ }^{\circ} \mathrm{C}\right)$
Fig. 7: Chemical structure<smiles>O=c1c(O[C@@H]2OC(CO)[C@@H](O)[C@H](O)[C@H]2O)c(-c2ccc(O)c(O)c2)oc2cc(O)cc(O)c12</smiles>

\section{NMR Spectra}

H-NMR (DMSO) $\delta: 5.35$ (1H, d, H-1') $6.90\left(1 \mathrm{H}, \mathrm{d},-\mathrm{H}-5^{\prime}\right)$, $6.44(1 \mathrm{H}, \mathrm{d}, \mathrm{H}-8), 6.20(1 \mathrm{H}, \mathrm{d}, \mathrm{H}-6), 7.67\left(1 \mathrm{H}, \mathrm{d}, \mathrm{H}-6^{\prime}\right)$, $7.55\left(1 \mathrm{H}, \mathrm{d}, \mathrm{H}-2^{\prime}\right), 3.11$ (sugar), 2.5 (solvent peak) (Table 4 \& Figure 5). 


\section{Mass Spectra}

Mass spectra of the isolated compound showed peak $\mathrm{m} / \mathrm{z}$ at $464.3[\mathrm{M}+\mathrm{H}]$ (Figure 6).

\section{Melting point}

Melting point of the isolated compound was found to be $241^{\circ} \mathrm{C}-242^{\circ} \mathrm{C}$ (Table 5 ).

\section{DISCUSSION}

One compound has been isolated by column chromatography which was idetified as flavonoid by shinoda test and TLC. In UV spectroscopy flavonoid compounds revealed two characteristic UV absorption bands with maxima in the 240 to $285 \mathrm{~nm}$ and 300 to 550 $\mathrm{nm}$ range. UV spectral characteristics of individual flavonoids were including free Phenolic groups, oxidation pattern methoxy groups and the position of the linkage of sugar moieties (O-or-C glycosylation). The use of UV shift reagents such as $\mathrm{NaOH}$ produced bathochromic shift which provided very useful information for substitution patterns of many flavanoids.

From the above data of UV, it was revealed that isolated compound is having same chromophoric group and were probably flavonols $(\mathrm{OH}$ - group at position -3) i.e. 3 substituted flavonols. $\lambda_{\max 1}$ and $\lambda_{\max 2}$ indicated our isolated compound having substituted 3$\mathrm{OH}$ group. Bathochromic shift indicated $-\mathrm{OH}$ group in position 4' of cinnamoyl system. While the bathochromic shift in band-II is confirming the presence of the free $7-\mathrm{OH}$ group. In the IR spectral analysis, the Peak at $3346.97 \mathrm{~cm}^{-1}$, a broad band is most probably the result of $-\mathrm{O}-\mathrm{H}$ stretching vibrations of the phenol OH group. The peak at $2924.70 \mathrm{~cm}^{-1}$ showed C$\mathrm{H}$ Stretching. The peak at $1650.92 \mathrm{~cm}^{-1}, 1600.12 \mathrm{~cm}^{-1}$ indicates the presence of $-\mathrm{C}=\mathrm{O}$, Carbonyl group. The peak at $1454.39 \mathrm{~cm}^{-1} \& 1480.25 \mathrm{~cm}^{-1}$ indicates the presence of the benzene ring. The peak at $1365.07 \mathrm{~cm}^{-1}$ \& $1306.79 \mathrm{~cm}^{-1}$ indicated $-\mathrm{C}-\mathrm{OH}$ stretching. The peak at $1199.12 \mathrm{~cm}^{-1} \& 1110.40 \mathrm{~cm}^{-1}$ showed $-\mathrm{C}-\mathrm{OH}$ vibration (Phenol). The peak at $1054.62 \mathrm{~cm}^{-1}$ showed C-O stretching $\left(1^{\circ}\right.$ alcohol). The peak at $996.43 \mathrm{~cm}^{-1}$ \& $929.4 \mathrm{~cm}^{-1}$ showed the presence of disubstitution of the benzene ring. The peak at $593.37 \mathrm{~cm}^{-1} \& 592.86 \mathrm{~cm}^{-1}$ showed the presence of carbohydrate in an isolated compound. H-NMR gave three types of proton such as aromatic protons, hydroxyl protons and solvent peak. Mass spectra of the isolated compound showed one peak $\mathrm{m} / \mathrm{z}$ at 464.3 . Melting point was found to be same as reported in the literature of Isoquercitrin $\left(241^{\circ} \mathrm{C}\right.$ $242^{\circ} \mathrm{C}$ ). Characterization and confirmation of an isolated compound as isoquercitrin $\left(3,3^{\prime}, 4^{\prime}, 5,7-\right.$ Pentahydroxyflavone 3 - $\beta$-glucoside \& Chemical formula: $\mathrm{C}_{21} \mathrm{H}_{20} \mathrm{O}_{12}$ ) (Figure 7) was done by spectroscopic studies like UV-Visible and IR, NMR, Mass, melting point. In future, further more phytocological investigation can be done on isoquercitrin to be active as diuretic and antiinflammatory agent as whole herb of Hygrophila salicifolia (Acanthaceae) was described as antiinflammatory and diuretic agent in ayurveda.

\section{REFERENCES}

1. Mohammed Ali. Pharmacognosy. Edn 1, CBS Publisher; New Delhi, 2008, pp. 55-65.

2. Shah GL. Flora of Gujarat Stat. Edn 1, Vol.1, Sardar Patel University, Vallabh Vidyanagar, 1978, pp. 543-544.

3. Chattertee A. The Treatise of Indian medicinal plants. Edn 1, Vol. 5, National Institute of Scienec Communication and information Resources, New-Delhi, 1987; pp. 63-64.

4. Nadkarni KM. Indian Materia Medica.Popular Prakashan, Bo mbay, India, 1978, pp. 667-669.

5. Kirtikar, Basu BD. Indian Medicinal plants, 2nd ed, 3:Bishen Sing Mahindra Pal Singh Publications, 1933.pp 1864-1865.

6. Mukherjee KP. Quality Control of Herbal Drugs, Edn 1, Business Horizons, New Delhi, India, 2004, pp. 379-380.

7. Harborne J. Phytochemical Methods-A Guide to Modern Techniques of Plant Analysis. 3rd Ed. New Delhi: Springer Pvt. Ltd, 1998: 5-12.

8. Wagner H. Plant Drug Analysis-A Thin Layer Chromatography Atlas. 2nd Ed. New Delhi: Springer Pvt. Ltd, 2004: 332-333.

9. Silverstein RM, Bassler GC. Spectrometric Identification of Organic Compounds. 5th Ed. NewYork: John Wiley \&Sons Inc; 1991: 93-123.

10. Agrawal SS, Paridhavi M. Herbal Drug Technology. 1st Ed. Hyderabad: Universities Press Private Limited, 2007: 271286, 297.

11. Petrus AA, Hemalatha SS, Suguna G. Isolation and Characterisation of the Antioxidant Phenolic Metabolites of Boerhaavia erecta L. Leaves. J. Pharm. Sci. \& Res. 2012; 4 (7) 1856-1861.

12. Tiberti LA, Yariwake JH, Ndjoko K, Hostettmann K. On-Line LC/UV/MS Analysis of Flavonols in the Three Apple Varieties Most Widely Cultivated in Brazil. J. Braz. Chem. Soc. $2007 ; 18(1): 100-105$. 